\title{
CD4 T cells transduced with CD80 and 4-1BBL mRNA induce long-term CD8 T cell responses resulting in potent antitumor effects
}

\author{
Hyun-II Cho ${ }^{1 *}$, Hye-Mi Park ${ }^{2}$, Hyun-Jung Shon', Tai-Gyu Kim² \\ From Society for Immunotherapy of Cancer 29th Annual Meeting \\ National Harbor, MD, USA. 6-9 November 2014
}

\begin{abstract}
Therapeutic cancer vaccines are an attractive alternative to conventional therapies to treat malignant tumors, and more importantly, to prevent recurrence after primary therapy. However, the availability of professional antigenpresenting cells (APCs) has been restricted by difficulties encountered in obtaining sufficient professional APCs for clinical use. We have prepared an alternative cellular vaccine with CD4 T cells that can be expanded easily to yield a pure and homogeneous population in vitro. To enhance their potency as a therapeutic vaccine, in vitro expanded CD4 $\mathrm{T}$ cells were transfected with RNAs encoding the costimulatory ligands CD80, 4-1BBL, or both (CD80-T, 4-1BBL-T, and CD80/4-1BBL-T cells, respectively). We observed augmented cell vitality in CD80/4-1BBL-T cells in vitro and in vivo. Significant CD8 T cell responses eliciting in vivo proliferation and cytotoxicity were obtained with CD80/4-1BBL-T cell vaccination compared to CD80-T and 4-1BBL-T cell vaccinations. Furthermore, CD80/4-1BBL-T cell immunization resulted in curing established EG7 tumors, resulting in the generation of memory CD8 $\mathrm{T}$ cell responses, and elicited therapeutic antitumor responses against B16 melanoma. These results suggest that $\mathrm{CD} 4 \mathrm{~T}$ cells endowed with costimulatory ligands allow the design of effective vaccination strategies against cancer.
\end{abstract}

\section{Acknowledgements}

This study was supported by a grant of the Korean Health Technology R\&D Project, Ministry of Health \& Welfare, Republic of Korea (HI12C0759).

\section{Authors' details}

${ }^{1}$ Catholic Hematopoietic Stem Cell Bank, Cancer Research Institute, College of Medicine, The Catholic University of Korea, Korea, Republic Of. ${ }^{2}$ Dept. of

${ }^{1}$ Catholic Hematopoietic Stem Cell Bank, Cancer Research Institute, College of Medicine, The Catholic University of Korea, Korea, Republic Of Full list of author information is available at the end of the article
Microbiology, Catholic Hematopoietic Stem Cell Bank, College of Medicine, The Catholic University of Korea, Korea, Republic Of.

Published: 6 November 2014

doi:10.1186/2051-1426-2-S3-P264

Cite this article as: Cho et al:: CD4 T cells transduced with CD80 and 4-1BBL mRNA induce long-term CD8 T cell responses resulting in potent antitumor effects. Journal for ImmunoTherapy of Cancer 20142 (Suppl 3):P264.
Submit your next manuscript to BioMed Central and take full advantage of:

- Convenient online submission

- Thorough peer review

- No space constraints or color figure charges

- Immediate publication on acceptance

- Inclusion in PubMed, CAS, Scopus and Google Scholar

- Research which is freely available for redistribution 